\title{
THE ROLE OF SOCIAL MOVEMENTS IN THE RECOGNITION OF GENDER VIOLENCE AS A VIOLATION OF HUMAN RIGHTS: FROM LEGAL REFORM TO THE LANGUAGE OF RIGHTS*
}

\author{
MANUEL CALVO GARCÍA ${ }^{1}$
}

\begin{abstract}
The history of rights shows that the struggle for the recognition of women's rights was difficult enough and the recognition of the right of women to a life without gender violence has been even more difficult. With a perspective based in a socio-legal and critical approach, this article defends that the recognition of the right of women to a life free of gender violence must be seen as a conquest of the feminist movement and women's organizations. It was the struggle of the feminist movement which provided the catalyst for the recognition of women's rights and the specific right of women to a life free of gender violence and to protection against such violence. But not only the recognition, also the praxis of the right of women to a life free of gender violence is important. The right of women to a life free from gender-based violence cannot be fully realized without the implementation of this right at the international and the local level. The implementation of rights and the existence of social movements involved with the right to a life free from gender violence is decisive to transforms the demands for protection from violence and its eradication to be see not as a question of mercy, but as a question of justice; and putting the individual experiences of gender violence victims within a wider framework from which the abuse can be considered as a social problem.
\end{abstract}

Keywords: Violence against women; gender violence as a violation of human rights; human rights and social movements; feminist movement and women's organizations.

Summary: I. LEGAL REFORMS AND THE STRUGGLE AGAINST GENDER VIOLENCE; II. VIOLENCE AGAINST WOMEN AS A HUMAN RIGHTS VIOLATION; II.1. The recognition of women's rights as "human rights"; II.2. The specification of gender violence as a violation of rights; III. RIGHTS AGAINST GENDER-BASED VIOLENCE.

Gender violence was not regarded as being worthy of juridical intervention until quite recently. This obviously does not mean that it is a new phenomenon in our society. On the contrary, it has always existed. However, it was not acknowledged -being hidden behind the veil of "privacy" or "intimacy" or, even worse, it was justified within the context of a patriarchal ideology. Consequently, actions deserving social reproach as well as being against the most basic rights of equality and dignity of individuals-

* This work has been undertaken within the project 'The Treatment of Gender Violence in the Administration of Justice. Implementation and Effectiveness of LO 1/2004' (DER2014-55400-R).

1 Professor of Legal Philosophy and Sociology of Law, University of Zaragoza, Spain (mcalvo@unizar.es).

The Age of Human Rights Journal, 6 (June 2016) pp. 60-82 ISSN: 2340-9592 DOI: 10.17561/tahrj.v0i6.2930 
escaped legal and judicial intervention.

In the final decades of the last century, the activities of feminist groups and women's organisations -together perhaps with a modest contribution from scientific research- produced an awareness of the real significance and scale of a question of human nature of the utmost seriousness. Society and institutions in general became increasingly aware of this problem which eventually began to be regarded as being both reprehensible and punishable. Gradually, legal mechanisms of control and social integration began to produce measures -essentially punitive - to confront this problem. Little by little, legal action also became more extensive and mechanisms for intervention went further than merely punitive measures through the development of regulations and public policies aimed at preventing aggression and protecting the victims of gender violence.

The history of rights shows that while the struggle for the recognition of women's rights was difficult enough, the recognition of the right of women to a life without gender violence has been even more difficult. An illustration of this is the fact that the Convention on the Elimination of All Forms of Discrimination against Women (CEDAW) in 1979 did not specifically include gender violence. Subsequently, the General Recommendations $\mathrm{n}^{\circ} 12$ (1989) and $\mathrm{n}^{\circ} 19$ (1992) of the Committee on the Elimination of Discrimination against Women redressed this “oversight”, emphasising that gender violence is a form of discrimination against women. Here again, as will be explained in detail in this paper, it was the struggle of the feminist movement which, in parallel with the development of forms of legal intervention for the eradication of gender violence, provided the catalyst for the recognition of women's rights. This was, perhaps, the penultimate step in achieving the recognition of the specific right of women to a life free of gender violence and to protection against such violence. Progressively, through the activism of women's organisations and the feminist movement, it has come to be recognised that gender violence not only harms women's rights but is a clear violation of those rights.

The focus of this paper may be linked with the propositions of Charles Tilly (2004) when he posed the question "Where Do Rights Come From?". This is clearly a provocative title, like the thesis which this article contains. In Tilly's opinion, the question can be asked from an analytic philosophical, a metaphysical or a rational action standpoint. But he understands, along with Moore, Tarrow and other authors involved in socio-historical research, that rights are first "historical products" and second "outcomes of a struggle" (Tilly 2004: 273). The lack of attention to the political dimension of rights and to the relationship between social movements and human rights is quite difficult to explain (Stammers 2009). Given this background, the socio-juridical and critical perspective on which this work is based seeks to provide the conceptual and practical tools necessary to show these connections. More specifically, this approach allows the recognition and the praxis of the right of women to a life free of gender violence to be seen as a conquest of the feminist movement and women's organisations. 


\title{
I. LEGAL REFORMS AND THE STRUGGLE AGAINST GENDER VIOLENCE
}

Women's organisations made a decisive contribution to putting gender violence in the public arena and to developing mechanisms for its eradication by arguing that the problems of abused women were not simply individual problems, but a general social problem requiring political and juridical intervention. With this in mind, the feminist movement -especially at its early stages and particularly in the English-speaking worldfostered a strategy of social change based on policies of criminal intervention which marked the way ahead for the global movement against gender violence.

The demands for legal intervention should be analysed in relation to the need to break the dead weight of the veil of privacy prevalent in a liberal legal culture. The demands of the feminist movements for legal intervention in the sphere of private relationships was a direct result of the fact that family privacy had repeatedly been used as a justification for not allowing judicial interference in the private sphere which, it was claimed, should be kept outside the public scrutiny of the courts and legal intervention. As an example of this doctrine and its consequences, the decision of the Supreme Court of North Carolina given in the State versus A. B. Rhodes in 1868 is frequently cited:

\begin{abstract}
...however great are the evils of ill temper, quarrels, and even personal conflicts inflicting only temporary pain, they are not comparable with the evils which would result from raising the curtain, and exposing to public curiosity and criticism, the nursery and the bed chamber. Every household has and must have, a government of its own, modeled to suit the temper, disposition and condition of its inmates. Mere ebullitions of passion, impulsive violence, and temporary pain, affection will soon forget and forgive, and each member will find excuse for the other in his own frailties. But when trifles are taken hold of by the public, and the parties are exposed and disgraced, and each endeavors to justify himself or herself by criminating the other, that which ought to be forgotten in a day, will be remembered for life ${ }^{2}$.
\end{abstract}

This doctrine was repeated in innumerable subsequent judgements and persisted until the final decades of the last century, thereby guaranteeing criminal and civil immunity for aggressors (Siegel 1996).

The need to break with the sanctification of the private sphere drove the tendency of feminist movements to fight for state intervention. This proposition is defended by Kristin A. Kelly (2003: 59 ff.), concentrating more on the indirect symbolic functions of juridical intervention than on the direct social control functions of the legal norms. In this context, the author analyses the feminist movement against domestic violence in the USA in the 1970s, a movement which emerged from the public exposure of such violence, from the perspective of the awareness of the problem which had the effect of battered women starting to share experiences -which contributed to deprivatizing the problem. This strategy is considered from the perspective of a movement of abused women fundamentally in the fight to achieve reforms "that would

\footnotetext{
${ }^{2}$ Available at: http://faculty.uml.edu/sgallagher/StatevRhodes.htm [last visited: January - 2015].
} 
make the legal system take domestic violence more seriously” (Kelly 2003: 68).

The "juridification" of domestic violence was regarded as the most important means of achieving the recognition of gender violence within families as being a matter of public interest, and the law is seen in this sense as "the" instrument for definitively making it clear that domestic violence is a social problem. In countries where the law is considered to be one of the principal means of reinforcing values, the actions of feminist collectives and in particular of lawyers representing battered women focussed on developing legal and regulatory instruments aimed at empowering victims of abuse, both increasing their protection and at the same time increasing the sanctions against their assailants (Kelly 2003: 70).

This tendency resulted from the confluence of a series of factors which include, in the first place, the actions of women's movements and defenders of women victims of abuse in favour of using criminal law to provide justice and redress the lack of consideration of the rights of women who suffer violence for reasons of gender, which turned their situation into an issue of public and political concern. But also, in the second place, because the policies of control make criminal law an area particularly attractive for legal reform and, what's more, at "low cost" 3 .

Legal reform as a strategy against domestic violence was largely based on the indirect symbolic functions of juridical intervention and, in particular, of criminal reform, showing a clear tendency to use coercive judicial mechanisms to solve "social problems” and especially to deal with the phenomenon of violence against women ${ }^{4}$. In this context, the social demands of women turned into juridical demands. More specifically, these reforming processes were principally focussed on criminal law, which contributed to effecting a reduction in the objectives and actions in the struggle to end gender violence. Furthermore, a strategy based on legal reform structured around criminal reform can be seen as one of the conditions responsible for the initial lack of debate about human rights in the USA ${ }^{5}$ and in other ambits (Bodelón 2012).

On the other hand, the margins of the welfare state opened up important areas of action for social reformers. The movement of women against domestic violence started from the bottom up, initially with the setting up of refuges for victims of abuse in the early 1970s, first in the UK (1972) and almost simultaneously in the USA (Minnesota, 1973; Boston, 1974) ${ }^{6}$. The women's movement developed from these initiatives and

\footnotetext{
3 "Many politicians who oppose increases in public expenditure on 'social programmes' are more than happy to allocate resources to 'the fight against crime”” (Coker, 2001: 802-3).

4 Buzawa and Buzawa 2003: 4. This trend is changing as can be seen in the fourth edition of the cited work (Buzawa, Buzawa and Stark 2012: $11 \mathrm{ff}$.).

5 Schneider 2008: 358. The reflections made by Elizabeth Schneider, half way between legal activism directed towards social reform and theory, are especially interesting. In her opinion legal reform does not exclude a recognition of the possibilities of international human rights law as a valid instrument applicable at a local level (Schneider 2000: $53 \mathrm{ff}$.).

6 Dobash and Dobash 2003: 25 ff., 60 ff. This movement gradually became more widespread. In Spain the first refuges opened in Madrid in 1986 and in Barcelona in 1987 (Bodelón: 2002: 339-348).
}

The Age of Human Rights Journal, 6 (June 2016) pp. 60-82 ISSN: 2340-9592 DOI: 10.17561/tahrj.v0i6.2930 
gender violence started to become visible in society. But little by little the social movements also claimed the right to actively use the transforming ability of juridical mechanisms and this led to intervention from the social policies with the objectives of victims' protection and social transformation. As R. Emerson Dobash and Russell P. Dobash point out, "interventionist and welfare states provide greater opportunities for reformers attempting to effect changes within the institution of the state. The goal may be to introduce state involvement where once there was none or to alter existing policies, practices and legislation relating to particular groups or social issues". Women's movements frequently resorted to this alternative. The authors continue emphasizing the point that "it is critical that the battered women's movements in Britain and the USA began in the 1970s when governments were generally more interventionist and welfare oriented" (Dobash y Dobash 2000: 189).

In short, legal reform led to considerable advances, but eradicating gender violence and stamping out its causes required going one step further: to open the door to women's rights and to seek intervention from the perspective of formulating policies to transform social relations in order to put an end to the discrimination and power asymmetry which feed gender violence. Why is it that such a commitment was not made in 1970 when the first steps towards legal reform were taken? Simply because the "right" of women to a life free of gender violence and to protection against such violence was not taken into account either at local or international levels. The idea of gender violence as a violation of a specific right of women took a long time to arrive. It took hold in the mid 1980s and particularly in the 1990s when the language of rights entered into the discourse and the political struggle of women to eradicate gender violence$^{7}$. From then onwards, gender violence began to feature more prominently in the international agenda of organisations defending women's rights and was finally considered both nationally and locally as a violation of those rights.

\section{VIOLENCE AGAINST WOMEN AS A HUMAN RIGHTS VIOLATION}

\section{II.1. The recognition of women's rights as "human rights”}

The omission of women's rights or their relegation to a position of minor importance in the most significant legal reforms of the 1970s and 1980s was the result of the omission of women in the general discourse of rights. If the $19^{\text {th }}$ century was the century of the rights of "man", much the same can be said of most of the $20^{\text {th }}$ century. Quite apart from this play on words, it has to be said that the omission of women from international human rights law was not merely a linguistic slip. The Charter of the United Nations made way for the development of women's rights, but the Universal Declaration of Human Rights persisted with the omission, which was not merely a

\footnotetext{
7 Sally Engle Merry (2009: 25) explains that in the 1970s and 1980s the movement against the abuse of women showed domestic violence to be a social problem and identified it as gender violence. Later, especially in the 1990s, these movements began to be associated with the human rights movement at both a national and an international level.
}

The Age of Human Rights Journal, 6 (June 2016) pp. 60-82 ISSN: 2340-9592 DOI: 10.17561/tahrj.v0i6.2930 
question of terminology. When the option of giving some prominence to women in the text of the Declaration was excluded from the drafting discussions, this also represented a rejection of the opportunity to emphasize the equivalence of the rights of women and men. In the interests of apparent universality and neutrality, a more decisive declaration in favour of the eradication of gender discrimination and the defence of the specific rights of women was left aside.

Women's rights made progress thanks to the incorporation of women into international organisations and the activities of women's organisations. The first significant advance in the development of women's rights occurred with the setting up of the Commission on the Status of Women within the framework of the United Nations. The advance of women in the public sphere at the time in which the Universal Declaration appeared was not reflected in the text, but it was an unavoidable reality. Arvonne S. Fraser (2007: 43 ff.) gives a detailed description of this important period in the origins of women's rights. According to her, the development of women's organisations and the increasing presence of women in national delegations was the result of the progress made by the women's movement. Women had begun to access the labour market, the suffragettes had been successful in 31 countries and gradually, led by delegates from Latin American countries, women began to have a clear presence in the United Nations. Minerva Bernardino of the Dominican Republic, one of the four women who signed the Charter of the United Nations, proposed the creation of a Committee within the framework of the Commission on Human Rights to work on the promotion of women's rights. After overcoming numerous objections, initially including the opposition of the powerful Eleanor Roosevelt, the Commission on the Status of Women of the United Nations was finally established on 21 June 1946.

This Commission played a fundamental role in the development of women's rights. It was responsible for the drafting of the Declaration on the Elimination of Discrimination against Women, adopted by the General Assembly on 7 November 1967, the precursor of the Convention on the Elimination of All Forms of Discrimination against Women, adopted in 1979. The Commission on the Status of Women of the United Nations also organised the United Nations Decade for Women and the World Conferences on Women held in Mexico, Copenhagen and Nairobi ${ }^{8}$.

These initiatives changed the discourse of the United Nations and gave rise to the emergence of women as political agents and as having human rights, overcoming the limitations of discourses anchored in the language of the traditional "family of nations", with its stereotypes and its implicit subordination of women. Networks and organisations of women with political experience demanded an end to sexual stereotypes and gender discrimination. They used the platform of the United Nations to

\footnotetext{
8 This Decade was started after the World Conference of the International Women's Year held in Mexico City in 1975 and continued until 1985. During the decade two other World Conferences on Women were held: the World Conference on the United Nations Decade for Women: Equality, Development and Peace (Copenhagen, 1980) and the World Conference to Review and Appraise the Achievements of the UN Decade for Women (Nairobi, 1985).
}

The Age of Human Rights Journal, 6 (June 2016) pp. 60-82 ISSN: 2340-9592 DOI: 10.17561/tahrj.v0i6.2930 
exercise their rights, opportunities and responsibilities in equal measure to men, and to create a new international order - economic, social and political ${ }^{9}$.

Another fundamental milestone in this period was the Convention on the Elimination of All Forms of Discrimination against Women ${ }^{10}$. This Convention completed and gave legal backing to the Declaration on the Elimination of Discrimination against Women, stating the degree of concern regarding the continuance of generalised discrimination against women despite the Charter of the United Nations, the Universal Declaration of Human Right, the International Covenant on Economic, Social and Cultural Rights and the International Covenant on Civil and Political Rights (Gómez-Isa 2003: 298 ff.; Southard 1996). The adoption of the CEDAW was followed by a large number of international and regional human rights instruments. National governments were obliged to adopt measures and policies leading to the protection, observance and application of the rights of women ${ }^{11}$.

These initiatives gained strength in a widespread and influential movement which contributed decisively to the recognition of women in the international sphere. The feminist movement had for many decades ignored the need to respond to the praxis of human rights that clearly failed to recognise women's rights. In the 1980s a movement for the defence of women's rights emerged internationally from the grassroots of civil society which articulated the slogan "women's rights are human rights". This bottom-up movement was involved in various activities ranging from the organisation of a defence network for the rights of women in the Philippines to the Encuentro feminista de mujeres latinoamericanas y del Caribe (Feminist Meeting of Latin American and Caribbean Women) in Bogotá (1981), which declared 25 November as the International Day for the Elimination of Violence against Women, and many other specific initiatives organised all over the world (Reilly 2009: 71). One of the most fruitful manifestations of this movement was related to the emergence and initiatives developed around the Global Campaign for Women's Human Rights and its Global Tribunal on Violations of Women's Human Rights ${ }^{12}$.

Taking this process as a basis, Niamh Reilly has convincingly argued that the progress of women's rights in the 1980s "did not happen suddenly or by accident. It was the result of well-organized, broad-based, transnational collaboration among diverse women's rights advocates and NGOs -wherein the activities of the Global Campaign for Women's Human Rights played a major part” (Reilly 2009: 73). Although the

\footnotetext{
9 Zinsser (2002: 144) has shown that the official documents of the Decade reveal that women had in fact modified the prevailing discourse.

10 Convention on the Elimination of All Forms of Discrimination against Women, 18 December 1979. It came into force on 3 September 1981. At the time of writing, 188 countries have ratified the Convention [https://treaties.un.org/pages/viewdetails.aspx?src=treaty\&mtdsg_no=iv-8\&chapter=4\&lang=en, last visited January 2015], attesting to the weight of the treaty in the international sphere of human rights. For the history of the Convention, see Reilly 2009: $46 \mathrm{ff}$.

11 For an up-to-date account of the impact of the CEDAW, see Englehart and Miller (2014: $25 \mathrm{ff}$.).

12 See Bunch and Reilly (1999) for a detailed description of the bottom-up organisational features and the strategies of both campaigns, together with the main documentary sources.
}

The Age of Human Rights Journal, 6 (June 2016) pp. 60-82 ISSN: 2340-9592 DOI: 10.17561/tahrj.v0i6.2930 
women's movement developing from the Decade and the United Nations conferences in 1975-1985 and culminating in the 1990s was very complex and was not free from the ideological and political struggles of the period (Ghodsee 2010: 3-12, Olcott 2010), there is absolutely no doubt that it provided the necessary spark and the decisive action in the period leading up to and during the World Conference on Human Rights held in Vienna in 1993, which finally resulted in women's rights being fully recognised as human rights ${ }^{13}$.

\section{II.2. The specification of gender violence as a violation of rights}

The issue of violence against women was first specifically raised in 1980 at the World Conference on the United Nations Decade for Women held in Copenhagen in the context of the struggle against discrimination and the emergence of women rights described above. Its 48 resolutions included one entitled "Battered women and violence in the family" in which it is stated that domestic violence and violence against women in general represent "a problem of serious social consequences that perpetuates itself from one generation to the next", a situation which is made more serious by the immunity from prosecution of persons who commit such acts of violence ${ }^{14}$. In fact, this issue had been a theme running through the debates and reports of the World Conference of the International Women's Year held in Mexico in 1975, and was even more apparent in the Third World Conference on Women which took place in Nairobi in 198515. It should be emphasized that these declarations were drafted within the context of the struggle for women's rights led by the feminist movement during the United Nations Decade for Women (1975-1985) ${ }^{16}$. It has also been pointed out that these developments were very much the result of the fact that the majority of the government delegates were women. Credit must also be given to the work of forums representing NGOs undertaken in parallel with these conferences (Reilly 2009: 5758) ${ }^{17}$.

13 UN-Vienna Declaration and Programme of Action, adopted by the World Conference on Human Rights on 25 June 1993, (A/CONF.157/23), paragraph 18.

14 UN-Report of the World Conference of the United Nations Decade for Women: Equality, Development and Peace, Copenhagen, 14-30 July 1980, A/CONF.94/35.

See: http://www.un.org/womenwatch/daw/beijing/copenhagen.html (last visited January 2015).

15 Paragraph 231 of the report of the Nairobi conference calls for the adoption of effective measures to identify, prevent and eradicate domestic violence against women and children and the implementation of all kinds of measures for their protection and to impose sanctions on those guilty of such acts of violence. UN-Report of the World Conference to Review and Appraise the Achievements of the United Nations Decade for Women: Equality, Development and Peace (Nairobi, 15-26 July 1985) United Nations, New York, 1986. Nairobi Forward-looking Strategie [http://www.un.org/womenwatch/confer/nfls/].

16 UN-Advancement of Women, In-depth study on all forms of violence against women: Report of the Secretary-General (A/61/122/Add.1), 2006, (A/61/122/Add.1), p. 16 s. Subsequently published as: Ending violence against women: from words to action. Study of the Secretary-General, electronic resource: http://www.un.org/womenwatch/daw/vaw/publications/English\%20Study.pdf (last visited January 2015). This study includes contributions from a wide-ranging group of experts and is an important reference for the development of the right of women to a life free from gender violence.

17 For the role of NGOs in this process, see Tinker 1999: $95 \mathrm{ff}$.

The Age of Human Rights Journal, 6 (June 2016) pp. 60-82 ISSN: 2340-9592 DOI: 10.17561/tahrj.v0i6.2930 
The discourse on violence against women in the 1970s and 1980s was closely connected with the language of legal reform and the urgency of making progress in protecting victims and prosecuting aggressors. However, despite some exceptions, there was little direct use of the language of rights ${ }^{18}$. This may be the explanation for the "oversight", mentioned above, of gender violence in the CEDAW and its revival in the discourse and the claims of women's rights in the 1980s. The feminist movement had based its demands for legal and social intervention on facts. Scientific knowledge and the work of women's organisations had brought to light a reality which was very widespread in our society and which it was difficult to continue to ignore behind the veils of intimacy or the private sphere. This knowledge and the existing data also began to be taken into account in the feminist movement for the defence of women's rights and gradually permeated the activities of international organisations. The culmination of this process, which brought gender violence and especially domestic gender violence out into the open, can perhaps be found in the study on the extent of domestic violence published in $1989^{19}$.

The above explains why the consideration of gender violence as a violation of women's rights was given after the adoption of the CEDAW in two general recommendations of the Committee on the Elimination of Discrimination against Women: General recommendation No. 12, eighth session, 1989; and General recommendation No. 19, eleventh session, $1992^{20}$. These recommendations place a specific obligation on states party to the Convention to protect women from any type of violence, including gender violence in the domestic sphere ${ }^{21}$. The Committee firmly establishes in General recommendation No. 19 that violence against women is a further form of discrimination against women "that seriously inhibits women's ability to enjoy rights and freedoms on a basis of equality with men”. First, it establishes as a general observation that the definition of article 1 of the Convention:

\begin{abstract}
...includes gender-based violence, that is, violence that is directed against a woman because she is a woman or that affects women disproportionately. It includes acts that inflict physical, mental or sexual harm or suffering, threats of such acts, coercion and other deprivations of liberty. Gender-based violence may breach specific provisions of the Convention, regardless of whether those provisions expressly mention violence (paragraph 6).
\end{abstract}

In virtue of this, it is concluded that:

Gender-based violence, which impairs or nullifies the enjoyment by women of human rights and

\footnotetext{
18 Paradoxically, while questioning the omission of women's rights in the discourse on human rights, Frank Hosken makes no reference to violence against women in his presentation to a "symposium on Women and International Human Rights" held at the time to define the rights of women (Hosken 1981: 110).

19 Centre for Social Development and Humanitarian Affairs - Office of the United Nations in Vienna, Violence Against Women in the Family, United Nations, New York, 1989.

20 Freeman et al., 2012: $447 \mathrm{ff}$.

21 Freeman et al., 2012: $454 \mathrm{ff}$.
}

The Age of Human Rights Journal, 6 (June 2016) pp. 60-82 ISSN: 2340-9592 DOI: 10.17561/tahrj.v0i6.2930 
fundamental freedoms under general international law or under human rights conventions, is discrimination within the meaning of article 1 of the Convention (paragraph 7)22.

Another of the fundamental advances of this Recommendation is to put an end to the argument that gender violence can not be considered a violation of rights on the grounds that it originates in private acts or in the private sphere ${ }^{23}$. Thus, it states that:

discrimination under the Convention is not restricted to action by or on behalf of Governments (see articles 2(e), 2(f) and 5). For example, under article 2(e) the Convention calls on States parties to take all appropriate measures to eliminate discrimination against women by any person, organization or enterprise. Under general international law and specific human rights covenants, States may also be responsible for private acts if they fail to act with due diligence to prevent violations of rights or to investigate and punish acts of violence, and for providing compensation (Paragraph 9).

In short, violence against women was explicitly considered as a violation of women's rights for which states have responsibilities and obligations. For this reason, states were requested to inform the Committee of measures adopted to overcome such violence ${ }^{24}$. Similarly, with the coming into force of the Optional Protocol to the Convention on the Elimination of All Forms of Discrimination against Women ${ }^{25}$ states were given the opportunity to report to the Committee on any violation of rights related with the prohibition of gender violence as set out in the Convention in accordance with the interpretations of the General Recommendations 12 and 19 (Facio et al 2009: 79 ff.).

As stated above, another important landmark in the definitive incorporation of the language of rights in the fight against gender violence can be found in the World

22 General recommendations adopted by the Committee on the Elimination of Discrimination against Women (CEDAW) [http://www.un.org/womenwatch/daw/cedaw/recommendations/index.html, last visited January 2015].

23 The duality of public-private spheres has served to avoid scrutiny on the part of international human rights law of private acts of torture and abuse and, in particular, to cover up the "subordination of women in the private sphere”. Vid. Chinkin (1999: 392 ff.). The reflections of Hilary Charlesworth (1999: 382383) are of interest here, pointing out that the consequences of this distinction are not neutral from the gender perspective given that in our society men dominate the public spheres of politics and government while women tend to see themselves as being more limited in the private sphere of the home and the family.

24 Rashida Manjoo, Report of the Special Rapporteur on violence against women, its causes and consequences, submitted to the General Assembly, 1 August 2011 (A/66/215): “19. The prevalence of violence against women remains a global concern. For example, in the majority of the 21 countries considered by the Committee on the Elimination of Discrimination against Women in 2010, representing all regions, prevalence of violence was either high, persistent or on the increase. The Committee had already explicitly linked discrimination against women and gender based violence in its general recommendations No. 12 (1989) and No. 19 (1992). It constantly calls on States parties to include in their reports to the Committee information on violence and on measures introduced to overcome such violence". Avalaible at:

http://daccess-dds-ny.un.org/doc/UNDOC/GEN/N11/439/45/PDF/N1143945.pdf?OpenElement,

last visited January 2015

25 Resolution of the General Assembly, October 1999 (A/RES/54/4). This protocol came into force on 22 December 2000 and was ratified by Spain in July 2001. Vid., on the protocol, Felipe Gómez Isa (2003: 291-321).

The Age of Human Rights Journal, 6 (June 2016) pp. 60-82 ISSN: 2340-9592 DOI: 10.17561/tahrj.v0i6.2930 
Conference on Human Rights held in 1993 which, as we have seen, asked the General Assembly to adopt the draft Declaration on Violence against Women and urged states to combat violence against women in accordance with the terms of the Declaration ${ }^{26}$.

Following the demands made at the Vienna Human Rights Conference in 1993 and the transformation of the claims occurring in the feminist movement ${ }^{27}$, the General Assembly adopted the Declaration on the Elimination of Violence against Women at the end of 1993. The Declaration makes it clear that violence against women is not only an obstacle to achieving equality, development and peace, as recognised by the Nairobi conference. It also represents an obstacle to the full application of the Convention on the Elimination of All Forms of Discrimination against Women. Following Recommendation 19 of the Committee it categorically states that "violence against women constitutes a violation of the rights and fundamental freedoms of women and impairs or nullifies their enjoyment of those rights and freedoms". This Declaration is drawn up from a gender perspective, clearly stating that:

violence against women is a manifestation of historically unequal power relations between men and women, which have led to domination over and discrimination against women by men and to the prevention of the full advancement of women, and that violence against women is one of the crucial social mechanisms by which women are forced into a subordinate position compared with men 28.

Another fundamental step in the recognition of the right of women to a life free of gender violence was Resolution 1994/45 of the Commission on Human Rights, adopted on 4 March 1994, under which it was decided to appoint a Special Rapporteur on violence against women, including its causes and consequences ${ }^{29}$. This established the first human rights mechanism specifically to deal with violence against women. Radhika Coomaraswamy from Sri Lanka was appointed as the first Special Rapporteur ${ }^{30}$. Her mandate was to seek and receive information from governments on

26 Vienna Declaration and Programme of Action adopted by the World Conference on Human Rights on 25 June 1993 (A/CONF.157/23), paragraph 38.

27 Sylvia Walby (2002) makes the following interesting reflection: "By the early 1990s this demand to stop men's violence against women ... was translated into language and concepts more appropriate for the predominantly male forum of the UN, that is the language of human rights rather than men's oppression of women. The demands were that women's rights were human rights, and that violence against women constituted a violation of women's human rights. This was a call for the transformation of the existing agenda of human rights and for a new interpretation that placed women's issues at the heart of the mainstream”.

28 Declaration on the Elimination of Violence against Women (A/RES/48/104). General Assembly resolution 48/104, 20 December 1993.

29 The United Nations Commission on Human Rights in resolution 1994/45, adopted on 4 March 1994, decided to appoint a Special Rapporteur on violence against women, including its causes and consequences. The mandate was extended by the Commission on Human Rights in 2003, at its 59th session in resolution 2003/45.

30 Radhika Coomaraswamy occupied the position until 2003. Her successor was Yakin Ertürk, from Turkey who held the post until 2009. Since then Rashida Manjoo, from South Africa, has been in the post.

The Age of Human Rights Journal, 6 (June 2016) pp. 60-82 ISSN: 2340-9592 DOI: 10.17561/tahrj.v0i6.2930 
violence against women, including domestic violence, and to recommend measures to eliminate such violence. Since 1994, by means of thematic reports, missions to various countries, consultations, meetings with experts, communications with governments and other mechanisms, the Special Rapporteur "has studied the forms, prevalence, causes and consequences of violence against women; analysed the legal and institutional developments in the protection of women against violence and the remaining challenges; and provided key recommendations to Governments and to the international community to overcome such challenges" 31 .

The continuity of these milestones can be seen in many other developments including the Fourth World Conference on Women (4-15 September 1995; Beijing, China). After recalling in paragraph 8 the need to implement the rights listed in the Declaration on the Elimination of Violence against Women, this Conference established in paragraph 29 of the Declaration and Platform for Action, as approved by governments, the need to "Prevent and eliminate all forms of violence against women and girls”.

From this moment on, several resolutions and reports were issued within the system of the protection of human rights of the United Nations. Among these, of particular note is the uncompromising stance against gender violence evident in the Report of the Special Rapporteur on torture and other cruel, inhuman or degrading treatment or punishment of 200832. In this report, citing Rhonda Copelon (1994), gender violence is treated as a cruel, inhuman and degrading form of torture or punishment. Parallels are drawn with various other forms of violence against women and other actions recognised as torture:

45. As with female detainees who experience torture, battered wives may be beaten with hands and objects, kicked, strangled, stabbed or burned. Rape and other forms of sexual abuse are used by intimate partners as well as by prison guards or police officers. In both scenarios, physical violence is usually accompanied by insults, varied forms of humiliation, and threats to kill or harm the victim or her family members (often children). Domestic violence, as well as torture, tends to escalate over time, sometimes resulting in death or leaving women's bodies mutilated or permanently disfigured. Women who experience such violence, whether in their homes or in a prison, suffer depression, anxiety, loss of selfesteem and a feeling of isolation. Indeed, battered women may suffer from the same intense symptoms that comprise the post-traumatic stress disorder identified in victims of official

31 Rashida Manjoo, Report of the Special Rapporteur on violence against women, its causes and consequences, submitted to the General Assembly, 1 August 2011 (A/66/215). Electronic version: http://daccess-dds-ny.un.org/doc/UNDOC/GEN/N11/439/45/PDF/N1143945.pdf?OpenElement (last visited January 2015). The report offers a general overview of the work carried out during her mandate, as well as her main conclusions and the remaining challenges. The document includes a list of reports made by the Special Rapporteur. For information about the role of the Special Rapporteur in connection with violence against women, its causes and its consequences, see Merino-Sancho 2012: $71 \mathrm{ff}$.

32 Manfred Nowak, Report of the Special Rapporteur on torture and other cruel, inhuman or degrading treatment or punishment, 15 January 2008 (A/HRC/7/3). Available at: http://daccess-dds-ny.un.org/ (last visited January 2015). The interpretation of gender violence given at this time by the Committee against Torture was also of fundamental importance: General Comment No. 2: Implementation of article 2 by States parties, 24 January 2008 (CAT/C/GC/2). Available at: http://docstore.ohchr.org/ (last visited January 2015). 
torture as well as by victims of rape. Another parallel between privately battering women and torture, which refers back to the element of powerlessness, is the intention to keep the victim in a permanent state of fear based on unpredictable violence by seeking to reduce the person to submission and destroy his/her capacity for resistance and autonomy with the ultimate aim of achieving total control.

In fact, this idea of considering violence against women as a form of torture had already been put forward in academic studies linked to legal activism against gender violence (Copelon 1994) and also by the Special Rapporteur in her report of 1996:

The argument that domestic violence should be understood and treated as a form of torture and, when less severe, ill-treatment, is one that deserves consideration by the rapporteurs and treaty bodies that investigate these violations together perhaps with appropriate NGO experts and jurists ${ }^{33}$.

It can be seen that the extension of the recognition of violence against women for reasons of gender has involved not only those organisations specifically concerned with the protection of women's rights. Little by little, it has also extended on an international level to those organs of the United Nations specifically concerned with the protection of human rights (Meyersfield, 2012: 58-79). With respect to the full recognition of gender violence as a violation of rights, especially noteworthy is the General Comment No. 28 of the Human Rights Committee which also links gender violence with torture and abuse as set out in article 7 of the International Covenant on Civil and Political Rights and which puts an obligation on states to provide "information on national laws and practice with regard to domestic and other types of violence against women”34.

The process of recognising gender violence as a violation of rights is also apparent in the actions of regional human rights protection organisations. Regional organisations have recognised violence against women as a violation of the human rights of women and have demanded that states guarantee these rights ${ }^{35}$.

As regards the Council of Europe, especially significant is the adoption of the Council of Europe Convention on preventing and combating violence against women and domestic violence (Istanbul, 11/05/2011). Article 3 makes it clear that under the terms of the convention violence against women is a violation of human rights and a form of discrimination against women, which must be seen from the gender perspective:

33 Radhika Coomaraswamy, Report of the Special Rapporteur on violence against women, its causes and consequences, submitted in accordance with the Commission on Human Rights resolution 1995/85. (E/CN.4/1996/53, Fifty-second session), paragraph 50. Available at: http://daccess-dds-ny.un.org/ (last visited January 2015)

34 Human Rights Committee, General Comment No. 28 Article 3 (The equality of rights between men and women), 29/03/2000 (CCPR/C/21/Rev.1/Add.10), pfo. 11.

35 Vid.Meyersfield 2012: 79-91. For a broader perspective focusing on legal discrimination, progress to date and the gap existing between the letter of regional mechanisms and actual practice, see Fareda Banda, Project on a Mechanism to Address Laws that Discriminate Against Women, Office of the High Commissioner for Human Rights/Women's Rights and Gender Unit, 2008: 23 ff. [http://www.ohchr.org/Documents/Publications/laws_that_discriminate_against_women.pdf, last visited May 2012]

The Age of Human Rights Journal, 6 (June 2016) pp. 60-82 ISSN: 2340-9592 DOI: 10.17561/tahrj.v0i6.2930 
"violence against women" is understood as a violation of human rights and a form of discrimination against women and shall mean all acts of gender- based violence that result in, or are likely to result in, physical, sexual, psychological or economic harm or suffering to women, including threats of such acts, coercion or arbitrary deprivation of liberty, whether occurring in public or in private life;

In other regional spheres various instruments have been adopted aimed at defining domestic and gender violence as human rights violations. The most relevant include the Inter-American Convention on the Prevention, Punishment and Eradication of Violence Against Women, known as the "Convention of Belém do Pará" as it was adopted in this Brazilian city in 1994, and The Protocol to the African Charter on Human and Peoples' Rights on the Rights of Women in Africa, known as the "Maputo Protocol", both of which guarantee the rights of women together with the protection of women against all forms of violence including gender violence.

The Convention of Belém do Pará states in article 3 that "every woman has the right to a life free of violence, both in the public and in the private sphere" and establishes an obligation on states to guarantee this right. Consequently, both the InterAmerican Commission on Human Rights and the Inter-American Court of Human Rights have acted to guarantee this right and other related rights (articles 4 and 5). Especially important is the decision of the Inter-American Commission on Human Rights in the case of Maria da Penha given on 16 April 2001 (Report $n^{\circ}$ 54/01, Case 12.051). This decision condemned the state of Brazil in the application of the Convention of Belém do Pará for not having intervened adequately in order to prevent and respond to the abuse of this woman. This decision obliged Brazil to enact a law against gender violence, the Ley Maria da Penha en defensa de los derechos de la mujer (Maria da Penha Law in defence of women's rights) ${ }^{36}$.

The other very relevant decision is the ruling of the Inter-American Court of Human Rights of 16 November 2009 in the case González y otras Vs. México ("Campo Algodonero"). This ruling concluded that the state had failed to comply with its duty to investigate - and thus its duty to guarantee- the rights enshrined in various articles of the American Convention on Human Rights and the Convention of Belém do Pará. The court also ruled that in this case the violence against the woman represented a form of discrimination. The state of Mexico was found guilty of human rights violations.

Turning now to the African human rights system, on 11 July 2003 The Protocol to the African Charter on Human and Peoples' Rights on the Rights of Women in Africa or the Maputo Protocol was adopted as an annexe to the Charter of 1986, specifically orientated to the recognition and protection of women's rights. This protocol came into force in 2005 and represents one of the bases for the recognition of the right of women to a life free of violence ${ }^{37}$. After defining the concept of violence against women from a

36 Law n ${ }^{\circ}$ 11.340, 7 August 2006. See Spieler 2011: $137 \mathrm{ff}$.

37 Meyersfield (2012: 90-91) has emphasized the importance of this text for the recognition of gender violence as a violation of rights, while pointing out that its implementation and effectiveness is another

The Age of Human Rights Journal, 6 (June 2016) pp. 60-82 ISSN: 2340-9592 DOI: 10.17561/tahrj.v0i6.2930 
gender perspective (article 1) and determining the obligation of states to prevent discrimination against women (article 2) and to ensure their dignity (article 3), it establishes in article 4.2 that:

States Parties shall take appropriate and effective measures to: a) enact and enforce laws to prohibit all forms of violence against women including unwanted or forced sex whether the violence takes place in private or public; b) adopt such other legislative, administrative, social and economic measures as may be necessary to ensure the prevention, punishment and eradication of all forms of violence against women; c) identify the causes and consequences of violence against women and take appropriate measures to prevent and eliminate such violence; d) actively promote peace education through curricula and social communication in order to eradicate elements in traditional and cultural beliefs, practices and stereotypes which legitimize and exacerbate the persistence and tolerance of violence against women; e) punish the perpetrators of violence against women and implement programmes for the rehabilitation of women victims; f) establish mechanisms and accessible services for effective information, rehabilitation and reparation for victims of violence against women; ...

This is a complete and categorical definition which speaks for itself, recognizing that gender violence is a violation of human rights and requiring the intervention of the public authorities to guarantee such rights in the private as well as the public sphere.

It is not only in the United Nations system but also in the regional systems of human rights where progress has been made in the recognition of the right of women to a life without violence, defining gender violence as a violation of rights and demanding the intervention of states and international organisations to protect and guarantee such rights. The struggle by women during decades has achieved first, the recognition of women's rights; second, bringing the reality of gender violence into the open together with the violation of rights inherent in its various forms; and, third, the recognition of the specific right of women to a life free of any kind of gender-based violence. International law and social and academic discourse recognise that gender violence is not only an attack on the rights of women, but is also a violation of the right of women to a life free of violence.

It has been a long process, but today it is at last unarguable that gender violence is a violation of human rights. At a local level, this process has been interrelated with advances in legal reforms and has furthered punitive strategies to the extent that gender violence has become regarded as a universal problem. This was pointed out by Jane R. Chapman (1990: 60) in her justification of the need to find space for the language of rights in the fight to end violence against women. Gender violence is certainly a crime, but it is much more than an offence. Therefore, if this social scourge is to be eradicated, it is essential to speak of it in the language of rights. Dealing with the problem in terms of human rights is especially productive because it provides a broader perspective without ignoring the advances implicit in criminal and other legal reforms.

\section{RIGHTS AGAINST GENDER-BASED VIOLENCE}

question.

The Age of Human Rights Journal, 6 (June 2016) pp. 60-82 ISSN: 2340-9592 DOI: 10.17561/tahrj.v0i6.2930 
The struggle for the recognition of gender-based violence as a violation of women's rights is of fundamental importance when attempting to extend the limits of a discourse based on the protection of civil rights and the politics of women. The recognition of the right to a life free of gender-motivated violence together with other rights pertaining specifically to women, in particular reproductive rights, take us much further than abstract ideas of equal treatment. They lead towards the recognition of rights vested in women in the broadest possible sense of the term and open the way to an acceptance of full equality without exceptions.

The developments examined in the previous section indisputably show that the right to a life free of gender violence has full recognition within the international system of human rights ${ }^{38}$. This recognition has important legal consequences. This point is made in a report drafted by a group of informed experts as follows:

There are important consequences that flow from categorizing violence against women as a matter of human rights. Recognizing violence against women as a violation of human rights clarifies the binding obligations on States to prevent, eradicate and punish such violence and their accountability if they fail to comply with these obligations. These obligations arise from the duty of States to take steps to respect, protect, promote and fulfil human rights. Claims on the State to take all appropriate measures to respond to violence against women thus move from the realm of discretion and become legal entitlements. The human rights framework provides access to a number of tools and mechanisms that have been developed to hold States accountable at the international and regional level. These include the human rights treaty bodies and international criminal tribunals, as well as the African, European and inter-American human rights systems ${ }^{39}$.

The recognition at an international level of the right of women to a life free of gender violence thus has significant legal implications in addition to political and social consequences. It puts an obligation on states to ensure this right is effectively exercised by implementing the appropriate legislative, administrative and other necessary measures. The right to a life free of gender-motivated violence can be exercised without any limitations or excuses based on arguments relating to the agency or the private sphere in which violations of this right are committed. States have responsibilities in the eradication of gender violence to guarantee women's rights. As a result, these rights are subject to the scrutiny of various human rights treaty bodies which monitor them from different perspectives (the Committee on the Elimination of Discrimination against Women, the Human Rights Committee, the Committee against Torture and the Committee on the Rights of the Child) and, where applicable, the object of communication by virtue of the corresponding Optional Protocol. They are also subject to examination and information-gathering under the terms of the mandates that protect such rights directly or indirectly, in particular by the Special Rapporteur on violence

\footnotetext{
38 After an exhaustive analysis, Bonita Meyersfield (2012: 106-107) concludes that from a technical point of view it is indisputable that the right can be exercised from the perspective of international law.

39 UN - ADVANCEMENT OF WOMEN, In-depth study on all forms of violence against women. Report of the Secretary-General, 2006 (A/61/122/Add.1), paragraph 39. This study included contributions from a wide range of experts and is an important reference point in the establishment of the right of women to a life free from gender violence.
}

The Age of Human Rights Journal, 6 (June 2016) pp. 60-82 ISSN: 2340-9592 DOI: 10.17561/tahrj.v0i6.2930 
against women, its causes and its consequences, and the Special Rapporteur on torture and other cruel, inhuman or degrading treatment or punishment. Similarly, in the regional sphere, the Council of Europe Convention on preventing and combating violence against women and domestic violence establishes monitoring and control measures by means of a Group of Experts and the Committee on action against violence against women and domestic violence ${ }^{40}$.

However, the right of women to a life free from gender-based violence cannot be fully realised without transferring the implementation of this right from the international to the local level. This message needs to be articulated in the discourse on rights at the local level where the appropriate actions also need to be taken to implement this right. Including this right with other fundamental rights protected in state constitutions such as the rights to liberty, equality, life, security and non-discrimination would establish guarantees of the protection and enforceability of this right at a local level.

As suggested above, there is still a long way to go before women's rights are fully and effectively achieved, especially the right to a life free from gender violence. The delay in the recognition of these rights says a great deal about the context and the prevailing ideology which for decades has put so many obstacles in the path to such recognition.

The struggle for the right of women to a life free from gender violence is marked by the need to address impediments to the main features of this right. In the first place, its recognition involves transformations and developments that must be considered as a "revolutionary and evolutionary process" (Thomas and Beasley 1995: 1147) in which the feminist movement and the involvement of women's organisations are fundamentally important, which could thus be characterised as a "bottom up" process both at the international and national levels. Secondly, the inclusion of the language of rights in the struggle against gender violence -admittedly a complex and dialectical process -initially occurs at an international level and thus requires putting this development into practice at a local level, based on the consideration of gender violence as a violation of rights.

The recognition of the right of women to a life free from gender violence has proved to be especially relevant in highlighting the influence of social movements in the recognition of rights and the actions of women's organisations in making such rights effective in practice. The legislative intervention against gender violence advocated within the framework of the legal reformism was at all times influenced by the actions of the feminist movement and women's organisations. Subsequently, in the last decades of the 20th century, the international human rights movement and national women's movements promoted the recognition of the right of women to a life free from gender violence and the consequent classification of gender violence as a human rights violation. In both cases, as shown in the previous section, the driving force behind women's human rights and their specific right to a life free from violence can be

40 This Convention came into force on 1/8/2014, after ratification by 10 states.

The Age of Human Rights Journal, 6 (June 2016) pp. 60-82 ISSN: 2340-9592 DOI: 10.17561/tahrj.v0i6.2930 
regarded as a "bottom up" process ${ }^{41}$.

The history of human rights shows the importance of enshrining these rights in legislation and in local practice to ensure their implementation. In other words, it is necessary to identify gender violence as a human rights issue in all contexts and at all levels (Thomas and Beasley 1995). The laws for eradicating gender violence should combine this action with the implementation of women's rights, incorporating developments in the international human rights system insofar as it relates to women's rights and also the recognition of fundamental rights such as those of liberty, equality, life, security and non-discrimination found in democratic constitutions ${ }^{42}$. The other step, also fundamental for achieving the desired objectives, is the incorporation of the language of rights in the practice and actions of social movements. This implies first introducing the language of rights in practice. Perhaps the fundamental step is introducing the language and the defence of rights in actions against gender violence in the courts and in those institutions responsible for prevention and the protection of victims. It is essential that the arguments based on the discourse of human rights and the advances in international human rights law should appear in judicial decisions. However, this obviously will not occur spontaneously ${ }^{43}$. This would require the active intervention of the women's movement and of human rights movements in general. Here it is important for women's organisations to include arguments and resources in their discourse and strategies based on those of international and national mechanisms for the defence of human rights, and at the same time for women to realise that their struggle is not a personal one to be faced in isolation, but that their actions involve the full realisation of human rights. This in turn means that all people involved professionally in actions against gender violence and the protection of its victims should be conscious of this perspective (Choudhry and Herring 2006; Morgaine 2006).

Perhaps the first question is how to help society and victims to treat the phenomenon of gender violence as a question of rights. It is clear that this is the first step towards reaching the point where all the actors involved in the fight against gender violence accept the language of rights and the possibilities that this perspective offers. Sally E. Merry has shown in several empirical research studies the way in which women victims of gender violence have come to realise that the aggression they suffer represents a violation of their rights ${ }^{44}$. She has made it clear that rights consciousness

${ }^{41}$ Merry et al. (2010) use this terminology, paraphrasing Santos and Rodríguez-Garavito, eds (2005).

42 This was done in Spain with the "Ley Orgánica 1/2004" of 28 December 2004 on "Medidas de Protección Integral contra la Violencia de Género" (Comprehensive Protection Measures against Gender-based Violence). From many points of view this legislative development is insufficient because the language of rights in this law does not recognize a "specific" right of women to a life free from gender violence. Nevertheless, it is an important step forward given that it clearly does use the language of rights in addressing gender violence.

43 For example, when addressing the constitutionality of the above-mentioned law, the Spanish Constitutional Court in its decision 59/2008 not only failed to directly recognize the right of women to a life free from gender-based violence, but paradoxically it also avoided using the language of rights in relation to the protection of victims and the eradication of gender violence.

44 Sally Engle Merry has conducted various empirical research studies demonstrating this process, arriving at conclusions that cannot be ignored. One of the first presentations of this research can be seen

The Age of Human Rights Journal, 6 (June 2016) pp. 60-82 ISSN: 2340-9592 DOI: 10.17561/tahrj.v0i6.2930 
does not precede their implementation. In fact, her investigations suggest that "implementation is fundamental to establishing human rights consciousness" (Merry 2003: 381). The adoption of the perspective of rights depends on a subjective construction that must be based on individual experiences lived in the social environment. Thus the implementation of rights and the existence of social movements involved with the human rights of women in practice, particularly their right to a life free from gender violence, is decisive (Merry 2003).

The intervention of women's movements based on the resource of human rights is fundamental for putting the individual experiences of gender violence victims within a wider framework from which the abuse can be considered as a social problem. This can lead to a collective identification which favours the development of an individual consciousness that must overcome the idea that gender violence is confined to a private and individual sphere (Schneider 1986: $611 \mathrm{ff}$.). Only this change motivated by the internalizing of the right to a life free from gender violence will allow women to go beyond moral judgements anchored in the breeding ground of a patriarchal society and the demands for protection from violence and its eradication to be met not as a question of mercy, but as a question of justice (Schneider 1986: 615, following Gilligan 1993: 128 ff.).

In conclusion, the implementation of women's rights in general and the right to a life free from gender-based violence in particular at a local level is fundamental. To achieve this, the rights must be passed into legislation and local practice at an institutional level in addition to the intervention of the women's movement and organisations. The incorporation of the language of rights can contribute to strengthening the actions of the women's movement against gender violence. Including the discourse of rights within the activism of social movements has been shown to be a positive element in achieving their objectives ${ }^{45}$. This has also been the case in the fight of the women's movement for the recognition of full equality, for their reproductive rights and for the eradication of gender violence. The impetus to achieving rights from the "bottom up" approach has an especially important transforming potential. However, as the experiences of the feminist movement in the defence of women's rights have shown, lowering the guard in the fight for women's rights could lead to the idea that once rights have been internationally recognised and implemented in national legislation, the obligations and responsibilities for the exercise of these rights lies with the state, an idea which could disarm the women's movement in its efforts for ensuring the effective realisation of such rights (Schneider 1986: 630). A more complex analysis of the mechanisms of social power and the design, on the part of the women's movement and organisations, of more wide-reaching actions of social intervention complementary to state intervention may perhaps result in a more productive strategy in terms of social change. To see legal change reflected in social transformations, it is

in Merry (2003: 343-381). She later considered the question within a much broader cultural perspective and provided comparisons with other research studies in Merry (2005: $179 \mathrm{ff}$.)

45 Obviously there are opinions to the contrary and, in general, about the limitations imposed by enclosing the feminist struggle in the discourse of rights (Elson 2006: 107 ff.; Nash 2002)

The Age of Human Rights Journal, 6 (June 2016) pp. 60-82 ISSN: 2340-9592 DOI: 10.17561/tahrj.v0i6.2930 
important for civil society to act in order to ensure the effectiveness of legally recognised rights and to take action which complements public policies.

\section{REFERENCES}

Banda, Fareda (2005). Women, Law and Human Rights: An African Perspective. Oxford: Hart. Banda, Fareda (2008). Project on a Mechanism to Address Laws that Discriminate Against Women, Office of the High Commissioner for Human Rights/Women's Rights and Gender Unit.

[http://www.ohchr.org/Documents/Publications/laws_that_discriminate_against_women.pdf, última consulta mayo 2012].

Bodelón, Encarna (2002). "El feminismo ante la violencia de género”, en Andrés García Inda y Emanuela Lombardo, coords, Género y derechos humano. Zaragoza: Mira Etrs, 2002, pp. 339-348.

Bodelón, Encarna ed. (2012). Violencia de género y las respuestas de los sistemas penales. Buenos Aires, Ediciones Didot.

Bunch, Charlotte y Niamh Reilly (1999). Demanding Accountability. The Global Campaign and Vienna Tribunal for Women's Human Rights, New Jersey: Rutgers University (Centre for Women's Leadership).

Buzawa, Eve S. y Carl G. Buzawa (2003). Domestic Violence. The Criminal Justice Response, 3th ed.. Thousand Oaks: SAGE.

Buzawa, Eve S., Carl G. Buzawa y Evan Stark (2012). Responding to Domestic Violence. The Integration of Criminal Justice and Human Services, 4th ed. Thousand Oaks: SAGE.

Calvo-García, Manuel (2003). El tratamiento de la violencia doméstica en la Administración de justicia, Madrid: Consejo General Poder Judicial.

Chapman, Jane Roberts (1990). "Violence against Women as a Violation of Human Rights". Social Justice vol. 17/2.

Charlesworth, Hilary (1999). "Feminist Methods in International Law”. The American Journal of International Law, 93/2: 379-394 http://dx.doi.org/10.2307/2997996

Chinkin, Christine (1999). “A critique of the public/private dimension”, European Journal of International Law 10/2: 387-395. http://dx.doi.org/10.1093/ejil/10.2.387

Choudhry S and Herring J (2006). "Righting Domestic Violence”. International Journal of Law, Policy and the Family 20/1: 95-119. http://dx.doi.org/10.1093/lawfam/ebi034

Coker, Donna (2001). "Crime Control and Feminist Law Reform in Domestic Violence Law: A Critical Review”. Buffalo Criminal Law Review 4/2: 801-860. http://dx.doi.org/10.1525/nclr.2001.4.2.801

Copelon, Rhonda (1994). "Recognizing the Egregious in the Everyday: Domestic Violence as Torture”. Columbia Human Rights Law Review 25: 291- 367.

Dobash, R. Emerson y Russell P. Dobash (2000). "The Politics and Policies of Responding to Violence Against Women”. In Jalna Hanmer and Catherine Itzin (ed.), Home Truths about Domestic Violence. Feminist Influences on Policy and Practice. A Reader. London: 
The Role of SOCial Movements in the ReCOGNition of Gender Violence as a Violation of HuMAN RightS: FROM LEGAL REFORM TO THE LANGUAGE OF RightS

Routledge.

Dobash, R. Emerson y Russell P. Dobash (2003). Women, Violence and Social Change, London, Routledge.

Elson, Diane (2006). “Women’s rights are human rights. Campaigns and Concepts”, in Lydia Morris (ed.), Rights: Sociological Perspectives. London: Routledge: 94-110.

Englehart, Neil A. \& Melissa K. Miller (2014). "The CEDAW Effect: International Law's Impact on Women's Rights". Journal of Human Rights 13/1: 22-47. http://dx.doi.org/10.1080/14754835.2013.824274

Englehart, Neil and Miller, Melissa K. (2011). "Women's Rights, International Law and Domestic Politics: Explaining CEDAW's Effectiveness.” APSA 2011 Annual Meeting Paper. Available at SSRN:http://ssrn.com/abstract=1902066

Facio, Alda et al. (2009). El Protocolo Facultativo de la Convención sobre la eliminación de todas las ormas de discriminación contra la mujer: Análisis de los casos ante el comité de la CEDAW, San José: Instituto Interamericano de Derechos Humanos.

Fraser, Arvonne S. (2007). “Becoming Human: The Origins an Development of Women's Human Rights”, en Marjorie Agosín, Women, Gender, and Human Rights. A Global Perspective, New Brunswick: Rutgers U. P.

Freeman, Marsha A, C. M Chinkin y Beate Rudolf (2012). The UN Convention on the Elimination of all Forms of Discrimination against Women. A Commentary, Oxford: Oxford University Press. http://dx.doi.org/10.5422/fso/9780199565061.001.0001

Ghodsee, Kristen (2010). "Revisiting the United Nations Decade for Women: Brief reflections on feminism, capitalism and Cold War politics in the early years of the international women's movement”, Women's Studies International Forum 33: 3-12. http://dx.doi.org/10.1016/j.wsif.2009.11.008

Gilligan, Carol (1993). In a Different Voice. Psychological Theory and Women's Development. Cambridge, MA: Harvard University Press.

Gómez Isa, Felipe (2003). “The Optional Protocol for the Convention on the Elimination of All Forms of Discrimination against Women: Strengthening the Protection Mechanisms of Women's Human Rights”. Arizona Journal of International and Comparative Law 20/2: 291-321.

Hosken, Fran P. (1981). "Toward a Definition of Women's Human Rights". Human Rights Quarterly 3/2: 1-10. http://dx.doi.org/10.2307/761853

Kelly, Kristin A. (2003). Domestic Violence and the Politics of Privacy. Ithaca: Cornell Univ. Press.

Merino-Sancho, Víctor M. (2012). Tratamiento Jurídico de las Demandas de Asilo por Violencia contra las Mujeres en el Ordenamiento Jurídico Español, Pamplona: CivitasThomson.

Merry, Sally Engel et al (2010). "Law From Below: Women's Human Rights and Social Movements in New York City". Law \& Society Review 44/1: 101-128. http://dx.doi.org/10.1111/j.1540-5893.2010.00397.x

Merry, Sally Engle (2003). "Rights Talk and the Experience of Law: Implementing Women's Human Rights to Protection from Violence”. Human Rights Quarterly 25/2: 343-381. http://dx.doi.org/10.1353/hrq.2003.0020

Merry, Sally Engle (2005). Human Rights and Gender Violence: Translating International Law into Local. Chicago: University of Chicago Press.

The Age of Human Rights Journal, 6 (June 2016) pp. 60-82 ISSN: 2340-9592 DOI: 10.17561/tahrj.v0i6.2930 
http://dx.doi.org/10.7208/chicago/9780226520759.001.0001

Merry, Sally Engle (2009). Gender Violence: A Cultural Perspective. Chichester, WileyBlackwell.

Meyersfield, Bonita (2012). Domestic Violence and International Law. Oxford: Hart.

Morgaine, Karen (2006) "Domestic Violence and Human Rights: Local Challenges to a Universal Framework”. J. Soc. \& Soc. Welfare 34/4: 109-129.

Nash, Kate (2002). "Human rights for women: an argument for 'deconstructive equality", Economy and Society 31/ 3: 414-433 http://dx.doi.org/10.1080/03085140220151873

O'Connor, Karen y Lee Epstein (1983). "Beyond Legislative Lobbying: Women's Rights Groups and the Supreme Court”. Judicature 67/3: 134-145.

Olcott, Jocelyn (2010). "Cold War Conflicts and Cheap Cabaret: Sexual Politics at the 1975 United Nations International Women's Year Conference”. Gender \& History Volume 22, Issue 3: 733-754. http://dx.doi.org/10.1111/j.1468-0424.2010.01614.x

Ptacek, James (1999). Battered Women in the Courtroom. The Power of Judicial Responses. Boston: Northeastern Univ. Press.

Reilly, Niamh (2009). Women`s Human Rights. Seeking Gender Justice in a Globalizing Age. Cambridge: Polity.

Santos, Boaventura de Sousa y Cesar A. Rodríguez-Garavito, ed. (2005). Law and Globalization from Below: Towards a Cosmopolitan Legality, Cambridge: Cambridge U. P..

Schneider, Elizabeth (2000). Battered Women and Feminist Lawmaking. New Haven: Yale University Press.

Schneider, Elizabeth A. (). "The dialectic of rights and politics: Perspectives from the women's movement”. New York University Law Review 61 (1986), pp. 589-652.

Schneider, Elizabeth M. (2008). "Domestic Violence Law Reform in the Twenty-First Century: Looking Back and Looking Forward”. Family Law Quarterly 42/3: 353-363.

Siegel, Reva B. (1996). “The Rule of Love. Wife Beating as Prerogative and Privacy”. Yale Law Journal 105/8: 2117-2207. http://dx.doi.org/10.2307/797286

Southard, Jo Lynn (). "Protection of Women's Human Rights under the Convention on the Elimination of All Forms of Discrimination against Women", Pace International Law Review vol. 8 (1996), pp. 1-90.

Spieler, Paula (). "The Maria de Penha Case and the Inter-American Commission on Human Rights: Contributions to the Debate on Domestic Violence against Women in Brazil”, Indiana Journal of Global Legal Studies 18/1 (2011), 121-143. http://dx.doi.org/10.2979/indjglolegstu.18.1.121

Stammers, Neil (2009). Human Rights and Social Movements. London: Pluto Press.

Thomas, Doroty Q. y Michele E. Beasley (1995). "Domestic Violence as a Human Rights Issue”. Albany Law Review 58: 1119-1147.

Tilly, Charles (2004). “¿De dónde vienen los derechos?”. Revista Sociológica 55: 273-300.

Tinker, Irene (1999). "Nongovernmental Organizations: An Alternative Power Base for Women?”. In Gender Politics in Global Governance, Mary K. Meyer y Elisabeth Prügl (ed.). New York: Rowman \& Littlefield, 1999.

Walby, Sylvia (2002). "Feminism in a global era". Economy and Society 31/4: 533-557. http://dx.doi.org/10.1080/0308514022000020670

Zinsser, Judith P. (2002). "From Mexico to Copenhagen to Nairobi: The United Nations Decade for Women, 1975-1985”, Journal of World History 13/1: 139-168. 
THe Role of SOCial MovementS in the ReCognition of GENDER Violence as a Violation of HUMAN RIGHTS: FROM LEGAL REFORM TO THE LANGUAGE OF RIGHTS

http://dx.doi.org/10.1353/jwh.2002.0028

The Age of Human Rights Journal, 6 (June 2016) pp. 60-82 ISSN: 2340-9592 DOI: 10.17561/tahrj.v0i6.2930 